\title{
Resistance To Brand Switching: The Elderly Consumer
}

Komal Gyani Karani, Lamar University, USA

Katherine A. Fraccastoro, Lamar University, USA

\begin{abstract}
In this study, the authors examine one more aspect of the elderly consumer's brand loyalty: resistance to brand switching. This study claims that elderly consumers are not only more likely to repurchase but also actively resist switching brands once they have established a favorite brand. This study looks at the unique cognitive psychology of elderly consumers likely to cause this behavior. A better understanding of such behavior can guide efforts of firms either trying to retain their existing consumers or attempting to convert customers of rival brands to their own brands.
\end{abstract}

Keywords: Brand switching; marketing; elderly consumers; quality of life

\section{INTRODUCTION}

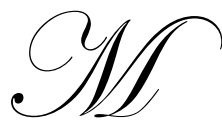

arketing firms have been long interested in retaining existing customers. It is well known that acquiring a new customer costs much more than retaining existing ones. Therefore it makes sense for firms to focus on their loyal customers and nurture those relationships. The elderly consumers have long been considered to be more prone to repurchasing known brands. With the increase in the elderly population due to the aging baby boomers, the elderly consumer group will become increasingly important to businesses. This paper examines the likelihood that elderly consumers are more resistant to brand switching than younger consumers and investigates the antecedents into the relationship.

Seniors typically have more disposable income than their children (Polyak 2000). At over $\$ 7$ trillion, seniors control 70 percent of the net worth of American households (Age Wave, LLC, 2000). With the first baby boomers moving into their mid-60s, senior citizens are the fastest growing demographic group in the USA. In 2010 there are roughly 50 million people in the USA age 65 and over, and by 2030, this figure is expected to rise to 70 million (Polyak, 2000), or one in every five persons (Federal Interagency Forum on Aging Related Statistics, 2000).

Brand loyalty has been usually measured by purchase behavior. For durables, purchase of the same brand twice has been considered evidence of loyalty (May, 1967). Brand loyalty for packaged goods has been measured by a buying unit's purchases going to one brand over a given period of time (Cunningham, 1961), sequences of brand purchases (Brown, 1952) and the number of different brands bought.(Farley, 1964) However, studies have also taken two different viewpoints of how the concept of brand loyalty can be applied. In one study of packaged goods, households were classified as brand loyal if they said they bought the same brand regularly and that they would go to another store or postpone purchase rather than buy another brand if their brand was out of stock. (Cunningham Scott, 1967) In a study of a food product, attitude toward a brand and the proportion of total purchases going to it were combined to measure loyalty (Day, 1969). These studies indicate that repurchase is not a sufficient measure of brand loyalty. A more meaningful measure would be buyer resistance to persuasion to switch brands (Newman \& Werbel, 1973). The elderly consumer's resistance to brand switching has received little attention in the literature. This study seeks to explaining the relationship between age and brand switching by taking brand loyalty a step beyond brand repurchase and considering other factors which are conducive to brand switching and how the elderly consumers are influenced by them. 


\section{LITERATURE REVIEW}

Two major factors must be considered when evaluating resistance to brand switching among the elderly consumer: Brand switching and the unique cognitive psychology of the older consumer which makes them less susceptible to brand switching and therefore more brand loyal.

\section{THE 'ELDERLY' CONSUMER}

Gerontology and psychology literature define 'elderly' differently from marketing literature. Most marketing studies used the term to describe all consumers over the age of 50. On the other hand, gerontology and psychology studies define 'elderly' as older than age 60 or 65. This study will use Schaie's (1996) categorization of the elderly, distinguishing "young-old" (ages 60-74) from "old-old" (age 75 and older). It is predicted that the "young-old" category of consumers will be closer to the middle-aged (ages 40-59) segment than the "old-old". Since the highly-educated baby boomers generation will soon be forming the bulk of the young-old category, this distinction is important. The baby-boomers generation is unlike previous generations in that they are healthier, better educated and wealthier as they near retirement. Therefore this study defines elderly consumers as belonging to the "old-old" age group or 75 years and older and studies how they are different from those younger than 75 years.

\section{BRAND SWITCHING}

Marketing literature shows a variety of reasons for brand switching in different product and service categories. However most of the work done is industry specific making generalizability difficult. Also, some studies cite conflicting reasons given by customers for their switching. Some of the reasons commonly given by customers of most categories are as follows (Keaveney, 1995):

1. Price. Price is one of the top reasons for many consumers to switch brands. In high price product categories, customers switched when prices exceeded internal reference prices. Prices could be considered too high relative to some internal normative price or too high relative to the value of the service or goods received, or too high relative to the competition. In case of price increase, customers compared the new increased prices to the prior reference price causing them to switch services or products. Customers' perception of unfair prices if they feel the price was unexpectedly high or greatly exceeded a quoted price also causes them to switch.

2. Service or Product Failure. This includes mistakes, billing errors, and service catastrophes.

3. Inconvenient Hours or Location of store. Customers can switch if the store switches location or hours making it inconvenient or inaccessible.

4. Competition. This involves customers switching because of competitor brands offering a better product or service.

5. Ethical problems. Four sub categories of unethical behavior cited by customers as reasons for switching are: dishonest behavior, intimidating behavior, unsafe or unhealthy practice, and/or conflicts of interest.

6. Involuntary switching. This occurs when the preferred brand is 'out of stock' in the store. The customer can respond by switching stores, postponing the purchase or switching brands.

7. Sales promotions. Several research studies have been carried out to study the effect of sales promotions. A key result is that the majority of the sales promotion elasticity (approximately 74 percent on average) is attributed to brand switching and the remaining is attributed to timing acceleration and quantity increases (Van Heerde et al, 2003).

\section{COGNITIVE DECLINE WITH AGE}

Baddeley's theory of working memory explains that to solve a problem, we rely on working memory, a critical component of an individual's information processing system consisting of a limited capacity work space that can be divided between storage and processing functions. Although limited working area presents a constraint regarding the amount of information a person can process while solving a problem for everyone, elderly consumers face an especially limited working memory. This may lead to unreliable structures because the products of earlier processing can be lost. This age-related decline in working-memory capacity seems to constrain performance 
especially on unfamiliar tasks (Salthouse, 1991). However when elderly adults solve familiar problems, they often perform as well as or better than younger adults (Charness, 1981). Although working-memory capacity diminishes with age, older adults can learn to compensate for such loss when they are familiar with the problem task (Smith and Moschis, 1990).

Four possible mechanisms may explain the effects of aging on consumer behavior (Lambert-Pandraud et al, 2005): Biological Aging, Cognitive Decline, Socioemotional Selectivity, and Change Aversion. Biological Aging indicates that physical capabilities decline with age; however, clear, biologically based slowdowns occur in daily social life only after an advanced age of 80 years or more. A majority of people between ages 60-74 report no serious problems relating to mobility. It's only after the age of 80 that more than half report that they shop only occasionally due to problems walking or driving.

Cognitive Decline suggests that older consumers' memory limits their consideration set to known or previously owned brands because they are no longer able to evaluate all the complex options available in minute detail. Research in cognitive psychology shows how cognitive capacities such as working memory decline with age. Working memory mediates the encoding of information in long-term memory and the conscious retrieval of recent events. From the age 60, people may also experience a reduction in their explicit memory which is what makes it possible to retrieve pieces of information and their sources consciously. Sorce (1995) suggests this is why older people often rely on store loyalty or an advice seeking heuristic. Also, information that is well learned and/or highly practiced also appears to be spared by aging. This may be another explanation for store and brand loyalty.

Socioemotional selectivity claims that older people who perceive their time horizon as limited place greater emphasis on feelings and emotions, such that their interest in new information declines. They give priority to close, well-known emotional contacts over new informative ones (Isaacowitz, Charles and Cartensen, 2000). This theory can provide yet another explanation why older people prefer to stick to their tried and tested brands and stores. This also explains why word -of -mouth from a trusted source will be more persuasive than any other form of publicity.

Change Aversion concerns how the elderly deal with changes. Elderly consumers show an aversion to change even if they are not particularly satisfied with their current state. Botwinick (1966) suggests two hypotheses to explain this. First, because of their intellectual decline, older people may avoid making decisions. Second, older people may avoid the risk that is associated with a bad decision, especially one that may lead to a financial risk. Thus, the purchase behavior of older consumers could be the consequence of change aversion, which could lead them to resist switching brands.

However, cognitive neuroscience shows that older adults often employ compensatory mechanisms which make up for some faculties which may be declining. Sometimes older adults may recruit additional resources to bolster their limited cognitive abilities and/or adopt different strategies than younger consumers to process information (Yoon et al, 2005).

\section{QUALITY OF LIFE ISSUES}

While little research has been conducted to assess consumption by the elderly with regard to quality of life, the issues concerning quality of life may also impact the elderly consumers' resistance to brand switching. Difficulties elderly consumers encounter with their daily lives may impact their life satisfaction and their ability to purchase their brand of choice. Factors related to quality of life such as family, friends, self, residence, health, fun and enjoyment, money, and job may affect their ability to participate in activities such as shopping as well as their purchase habits. Karatas and Duyan (2008) found that life satisfaction levels for consumer that have difficulty participating in activities that require physical effort is lower than those who do not have difficulty participating. Likewise, they found that life satisfaction levels of elderly consumers who have financial difficulties are lower than those who do not have financial difficulties. Given that ability to shop and the financial ability of the elderly consumer may constrain their purchase choices, it is likely that consumers with lower quality of life are likely to switch brands more than those with higher quality of life. 


\section{HYPOTHESES}

Price Sensitivity of the elderly consumers has been studied with varying and conflicting results over the years. Mason and Bearden stated in 1978 that elderly shoppers tend to be economy minded and shop alternative sources to find the best price. But a later study showed by Lumpkin and Greenberg (1985) showed that elderly consumers actually placed less emphasis on price and sales than younger consumers. Most subsequent studies have reinforced this viewpoint. One reason for this may be that prior to the 1980s, the older consumer was viewed as an underprivileged segment of the population, having limited economic resources (Moschis, 2003). If this view was not inaccurate, it is possible that elderly consumers in that time period were indeed more price sensitive. Since then, this segment has become economically stronger having even more disposable income than their children. This could result in reduced price sensitivity. Another reason could be that of risk reduction. The elderly consumers would rather accept some degree of price increase of a known and liked brand than take on the risk associated with trying out a new product.

H1: Elderly consumers are less likely than younger consumers (under 75 years of age) to switch brands because of a price increase.

Another leading cause for brand switching is attractive promotions being offered by competitors. However different studies show that sales promotions have limited appeal for the older consumer. For example, in a study of elderly apparel customers, Dodge (1958) found that $65 \%$ of the sample said they would not wait for a clothes sale to make their purchases. The reasons for this may be similar to the ones listed for the mature consumer's reduced price sensitivity.

H2: Elderly consumers are less likely than younger consumers to switch brands due to promotions by competitors.

A service or product failure makes it a risky repeat purchase. In the case of elderly consumers who are significantly more risk averse than younger consumers, that is more likely to be an important consideration in their purchase behavior. This is not because of 'cautiousness' as is often assumed. Elderly consumers evaluate risk in a similar manner as younger consumers. However, they are more likely to avoid making decisions which cause internal conflict or dissonance (Yoon et al, 2005). Other factors which have not yet been studied include the possible role of affect in decision making. Elderly consumers are known to be particularly influenced by affect when making choice decisions. Work by Bechara et al, (1996) suggests that affective reactions to experiences with an object drive the learning that subsequently guides choices. So, if the product or service failure and the subsequent recovery efforts were such that they created a negative affective response, it is unlikely that the elderly consumer will want to give the product another chance.

H3: Elderly consumers are more likely than younger consumers to switch brands because of a service or product failure.

In an Australian study, elderly consumers rated carrying equipment and product layout as two of the top three most relevant issues. Decreased muscle mass and frailty could be reasons why convenience of product layout and easy accessibility is considered to be so important to elderly consumers (Pettigrew, Mizerski \& Donovan, 2005). Store lighting and temperature were also very important to this segment of customers (Mason and Bearden, 1978). Barnes and Peters (1982) cited convenience as a major factor in deciding where to shop. Some components of convenience are fast checkout and package carryout (Lambert, 1979), ease of entrance and exit (Mason and Bearden, 1978), and knowledgeable sales personnel (Gelb, 1978).

H4: Elderly consumers are more likely than younger consumers to switch brands because of inconvenient location or layout of stores.

Age is negatively correlated with fluid intelligence (i.e. intelligence required for new problems and situations), but crystallized intelligence (i.e. intelligence based on prior experience and learning) remains intact (Salthouse, 1991). The decline of fluid intelligence passes through performance thresholds. As noted before, 
working memory also declines with age. Therefore, the decline in working memory and fluid intelligence should decrease the number of brands that older consumers consider and should increase their tendency to purchase familiar options over new brands, especially when evaluating them requires extensive problem solving.

H5: Elderly consumers are less likely than younger consumers to switch brands because of new product introductions by competitors where comparative analysis of options becomes cognitively difficult.

Older people share a sense of moral responsibility in their purchase behavior, and as a community are willing to engage in affirmative purchasing and boycotting (Carrigan, Szmigin \& Wright, 2004). One possible reason for this has been given by Titus and Bradford (1996) is that of time constraints. Younger consumers are prevented from being as sophisticated and ethical consumers as they would like because time constraints prevent them from seeking and absorbing the information required for careful analysis of the marketplace's offerings. On the other hand, older consumers have fewer time constraints due to retirement, empty nests etc. and may be more likely to absorb and act on ethical considerations. Also, 'green' products are often more expensive and since the older consumers are indicated to be less price conscious and have more disposable incomes than younger consumers, they may consider the additional expense more acceptable (Bainbridge, 1998). Also age, wisdom and experience as consumers have been shown to create more discriminating older buyers which may translate into ethical behavior (Corlett, 1998; Cowe \& Williams; Silvers, 2001). It is not known yet if this arises from a sense of self actualization or a desire to leave the world a better place for their children/grandchildren.

H6: Elderly consumers are more likely than younger consumers to switch brands because of ethical concerns with the manufacturing or retailing firm.

Sloot et al (2005) carried out a study to study the variables present in a situation where the desired product was out of stock. They found that the elderly consumer was more likely to switch stores rather than switch brands if their preferred brand was out of stock. One reason may be that elderly consumers have more spare time to shop and have fewer time constraints against switching stores to look for the brand of their choice. An older research by Peckham (1963) also found that older shoppers were less inclined to accept a substitute brand than younger ones. He found that $48 \%$ of shoppers over 50 years of age stated that they would not buy a substitute when the brand they wanted was unavailable as compared with $41 \%$ in the $25-50$ age range and $38 \%$ in the under 25 years bracket. This study treated the entire age-range of over 50 years as one category. It seems reasonable to assume that the age range of 75 years and above will be even more resistant to brand substitution.

H7: Elderly consumers are less likely than younger consumers to switch brands because of temporary out of stock situations.

The mature market is open to new products but not because it is 'trendy' or is being used by all their peers. The older consumers have knowledge based on experience helping them form instant perceptions of the product or service being offered. Rather than peer influence, they are more likely to try a product or service which satisfies a real, personal need (Leventhal, 1997).

H8: Elderly consumers are less likely than younger consumers to switch brands due to peer influence.

Several of the hypotheses listed contain issues that are related to quality of life. Quality of life measures assess the impact of one's family, friends, self, residence, health, fun and enjoyment, money, and job on his/her satisfaction with life (Roberts and Clement, 2007). When elderly consumers are having difficulty with specific aspects of their lives, it may affect their ability to remain loyal to certain products. For instance, if an elderly consumer is having physical difficulty, it may impact their ability to shop for the products they would prefer. If an elderly consumer is having financial difficulty, they may feel the need to switch to a lower priced product.

H9: Elderly consumers are more likely than younger consumers to switch brands due to lower quality of life. 


\section{MANAGERIAL IMPLICATIONS}

It is now being widely accepted that the retiring boomers will be one of the most influential segments in the market. Not only do they have more disposable income, they are also more brand loyal than the younger consumers, making them ideal customers. Their loyalty is not limited to repurchase behavior of their preferred brands. They are actually more resistant to brand switching which means it will be more difficult for competing firms to lure them away. However, this study attempts to show that they cannot be taken for granted since they have strong preferences for certain aspects of their shopping experience. By looking at which aspects affect them strongly enough to cause them to switch away from their preferred brands, this study indicates which factors firms need to assess more carefully.

\section{AUTHOR INFORMATION}

Komal Karani is currently an assistant professor of Marketing at Lamar University, Beaumont, Texas. She is completing her PhD from LeBow College of Business, Drexel University, Philadelphia. Her research interests include services marketing, satisfaction and quality, aging consumers and consumer behavior. She has published on these issues in conference proceedings such as Academy of Marketing Science.

Katherine Fraccastoro received her Ph.D. from Louisiana State University and is currently an associate professor of Marketing at Lamar University, Beaumont, Texas. Her research interests include consumer behavior issues related to product pricing, cultural acceptance issues, entrepreneurship, and marketing education. She has published several referred papers on these and related issues in conference proceedings and journals such as the Journal of Consumer Behavior, Marketing Letters, Journal of Higher Education Policy and Management, and Communications of the Association for Information Systems. Currently Dr. Fraccastoro is the William E. and Katherine F. Fouts Faculty Scholar in Business.

\section{REFERENCES}

1. $\quad$ Bainbridge J. (1998), "Baby boomers: a generation vexed", Marketing, 23, October, p.3

2. Barnes, N.G. \& Peters, M.J. (1982), "Modes of Retail Distribution: Views of the elderly", Akron Business and Economic Review, 13 (Fall), p.26

3. Bechara, A., Tranel, D., Damasio, H. and Damasio, A.R. (1996), "Failure to Respond Autonomically to Anticipated Future Outcomes Following Damage to Prefrontal Cortex", Cerebral Cortex, 6, p.215

4. Botwinick, J. (1966), "Cautiousness in Advanced Age”, Journal of Gerontology, 21 (July), p.347

5. Brown, G. H. (1952) "Coffee Buyers loyal to brands, Yet Two-Thirds buy four or more brands a year", Advertising Age, July 14, p.55-6

6. Carrigan M., Szmigin, I. \& Wright, J. (2004), "Shopping for a better world? An interpretive study of the potential for ethical consumption within the older market", The Journal of Consumer Marketing, 21, 6, Business Module, p. 401

7. Charness, N. (1981), "Aging and Skilled Problem Solving," Journal of Experimental Psychology: General, 110 (January) p.21

8. Corlett, C. (1998), "Shattering the stereotypes of the 50+ shopper: marketing", Vital Speeches of the Day, 64(15), p.478

9. Cowe, R. and Williams, S. (2001), "Who are the ethical consumers?" Co-operative Bank/Mori Survey, Cooperative Bank, London.

10. Cunningham, R. M. (1961), "Customer loyalty to store and brand", Harvard Business Review, 39, November-December, p.127-38

11. Cunningham, S.M. (1967) "Perceived Risk and Brand Loyalty," in Donald F. Cox, ed, Risk Taking and Information Handling in Consumer Behavior. Boston: Division of Research, Harvard University, p.507-23

12. Day, G. S. (1969) “A two-dimensional concept of brand loyalty," Journal of Advertising Research, 9, September, p.29-35

13. Dodge, R.E. (1985), "Selling the older consumer", Journal of Retailing, Summer, p.73-81.

14. Farley, John U. (1964) "Brand Loyalty and the Economics of Information", Journal of Business, 37, October, p.370-81 
15. Gelb, B. D. (1978), "Exploring the Gray Market Segment”, MSU Business Topics, 26 (Spring), p. 41

16. Isaacowitz, D.M., Charles, S.T. \& Cartensen, L.L. (2000), “Emotion and Cognition, 2d ed.' Fergus I.M. Craik and Timothy Salthouse, eds. London: Lawrence Erlbaum Associates, p.593

17. Karatas, K. \& Duyan, V. (2008), "Difficulties That Elderly People Encounter and Their Life Satisfaction", Social Behavior and Personality, 36(8), p.1073-1084

18. Keaveney, S. M. (1995), "Customer Switching Behavior in Service Industry: An Exploratory Study", Journal of Marketing, 59, April, p.71-82

19. Lambert, Z.V. (1979), “An investigation of Older Consumers: Unmet Needs and Wants at the Retail Level”, Journal of Retailing, 55, Winter, p.37

20. Lambert-Pandraud, R., Laurent, G., \& Lapersonne, E. (2005), "Repeat Purchasing of New Automobiles by Older Consumers: Empirical Evidence and Interpretations", Journal of Marketing, 69 (April), p.97

21. Levental, R.C., (1997) "Aging Consumers and their effects on the marketplace," The Journal of Consumer Marketing, 14, 4, p.276

22. Lumpkin, J.R., Greenberg, B.A., \& Goldstucker, J.L. (1985), "Marketplace Needs of the Elderly: Determinant Attributes and Store Choice", Journal of Retailing, 61, Number 2, Summer, p.75

23. Mason, J.B. \& Bearden, W.O. (1978), "Profiling the shopping behavior of elderly consumers", The Gerontologist, 18, October, p.454

24. May, F. E. (1967) "Adaptive Behavior in Automobile brand choices," Journal of Marketing Research, 7 (June). p. 62-5

25. Moschis G.P. (2003), "Marketing to older adults: an updated overview of present knowledge and practice", The Journal of Consumer Marketing, 20(6), p. 516

26. Newman J. W. \& Werbel, R.A. (1973), "Multivariate Analysis of Brand Loyalty for Major Household Appliances," Journal of Marketing Research, November, 10, p. 404-409

27. Peckham, J.O. (1963) “The consumer speaks", Journal of Marketing 27 (4), pp. 21-26.

28. Pettigrew, S., Mizerski, K. \& Donovan, R. (2005), "The three "big issues" for older supermarket shoppers", Journal of Consumer Marketing, 22(6), p.306

29. Polyak, I. (2000), “The center of attention", American demographics, 22(11), November, p. 30-2.

30. Roberts, J.A. \& Clement, A. (2007), "Materialism and Satisfaction with Over-All Quality of Life and Eight Life Domains", Social Indicators Research, 82, p. 79-92.

31. Salthouse, T. (1991), "Mediation of Adult Age Differences in Cognition by Reductions in Working Memory and Speed of Processing," Psychological Science, 2(May), p.179

32. Schaie, K.W. (1996), "Intellectual Development in Adulthood", in Handbook of the Psychology of Aging, J.E. Birren and K.W. Schaie, eds. San Diego: Academic Press p.266

33. Silvers, C. (1997), "Smashing old stereotypes of 50-plus America", Journal of Consumer Marketing, 14(4), p.303

34. Smith, R. \& Moschis, G.P. (1990), "The Socialization Approach to the study of the Elderly Consumer," Review of Marketing, ed. Valarie Zeithaml, Chicago: American Marketing Association, p.190

35. Sloot, L. M., Verhoef, P.C., \& Franses, P.H. (2005), "The impact of brand equity and the hedonic level of products on consumer stock-out reactions", Journal of Retailing, 81(1), p.15-34

36. Sorce, P. (1995), "Cognitive Competence of Older Consumers", Psychology and Marketing, 12 (6), p. 467

37. Titus, P.A \& Bradford, J.L. (1996), "Reflections on consumer sophistication and its impact on ethical business practice", Journal of Consumer Affairs, 30(1), p. 175

38. Van Heerde, H.J., Gupta, S., Wittinck, D.R. (2003), "Is 75[percent] of the Sales Promotion Bump Due to Brand Switching? No, Only 33 [percent] Is", Journal Of Marketing Research, 40(4), November, p. 481-91

39. Yoon, C., Laurent, G., Fung, H.H., Gonzalez, R., Gutchess, A.H., Hedden, T., Lambert-Pandraud, R.L., Mather, M., Park, D.C., Peters, E., \& Skurnik, I. (2005) "Cognition, Persuasion and Decision Making in Older Consumers", Marketing Letters, 16, 3/4, p. 429 
NOTES 